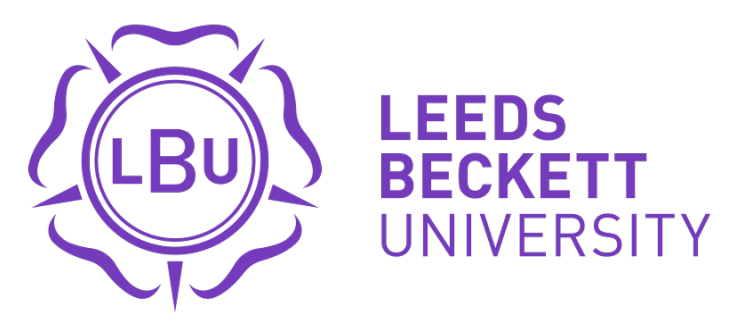

Citation:

Page, D (2020) The academic as consumed and consumer. Journal of Education Policy, 35 (5). pp. 585-601. ISSN 0268-0939 DOI: https://doi.org/10.1080/02680939.2019.1598585

Link to Leeds Beckett Repository record:

https://eprints.leedsbeckett.ac.uk/id/eprint/5801/

Document Version:

Article (Accepted Version)

This is an Accepted Manuscript of an article published by Taylor \& Francis in Journal of Education Policy on 29 March 2019, available online: http://www.tandfonline.com/10.1080/02680939.2019.1598585

The aim of the Leeds Beckett Repository is to provide open access to our research, as required by funder policies and permitted by publishers and copyright law.

The Leeds Beckett repository holds a wide range of publications, each of which has been checked for copyright and the relevant embargo period has been applied by the Research Services team.

We operate on a standard take-down policy. If you are the author or publisher of an output and you would like it removed from the repository, please contact us and we will investigate on a case-by-case basis.

Each thesis in the repository has been cleared where necessary by the author for third party copyright. If you would like a thesis to be removed from the repository or believe there is an issue with copyright, please contact us on openaccess@leedsbeckett.ac.uk and we will investigate on a case-by-case basis. 


\title{
The academic as consumed and consumer
}

\author{
Damien Page, Leeds Beckett University
}

Damien.Page@leedsbeckett.ac.uk

This is an Author's Accepted Manuscript of an article to be published in Journal of Education Policy, copyright Taylor \& Francis. 


\title{
The academic as consumed and consumer
}

\begin{abstract}
In an increasingly competitive environment that positions students as consumers, universities have become ever more marketised, responding to policy contexts that foreground value for money, consumer choice and competition. The intensity of marketisation is argued to have profoundly affected the nature of academic work and scholars themselves, recreating academics as commodities to be weighed and measured, becoming corporatised, alienated and inauthentic in their practice. Yet with the majority of accounts of the commodification of higher education focusing on students, the actual process of how academics become consumed is under-theorised. This article therefore begins with a discussion of the historical context, providing evidence of the familiar indices of marketisation such as rampant selfpromotion, the scramble for external funding and intense competition. It argues that this commodified DNA of the university provides the context for the seduction of the modern academic within the consumer society, a movement from the gratification of needs to the perpetual frustration of desires through the 'Diderot Effect' of policy shifts. It concludes with an examination of how contemporary academic work can be viewed through the lens of consumerism and how academics themselves have become consumers.
\end{abstract}

\section{Introduction}

While the marketization and commodification of higher education is a familiar field of debate, in the last 10 years, the consumerist turn has become ever more acute. With students increasingly positioned as consumers and universities adopting the cargo cult (Hood, 1991) of private sector practices, the neoliberal agenda has become firmly entrenched within academia. While there is considerable difference between university sectors internationally in terms of level of student fees, structural variations and the extent of state regulation, higher education has seen a global trend away from funding and regulation which were based on the 'social compact' that evolved between higher education, the state and society over the last century' (Naidoo, 2003). As a result, the commodification of academic labour is remarkably consistent across the globe. Kwiek and Antonowicz (2015) discuss the increasing competitiveness at all stages of academic careers across European universities, both in terms of gaining employment but also securing research funding seen as key to retaining employment. Despite idiosyncrasies between countries, universities across Europe are increasingly compelled to 'function in the state of permanent adaptation; adaptations are required as responses to changes both in their funding and governance modes' (p56). Here, we see the policy shifts that alters practice at the institutional level that then plays out at the individual level. This consistency of policy influence across European universities is also highlighted by Fumasoli, Goastellac and Kehm (2015) who narrow the focus to the primary influence of accountability and quality assurance imperatives that exert control over universities, central themes in Europe despite internal variations between countries. These imperatives have led, they argue, to increased competition both between universities but also between individual academics leading to a 'winner takes all' market, a market driven by global university rankings that have even affected major HE countries such as France and Germany (Erkkila, 2014). Elsewhere, higher Education in Africa is argued to be compelled by the marketisation of Europe and the US. Here, private universities, mirroring their US counterparts, 'exert considerable pressure on public universities, which in turn resort to the same market strategies' (Sall and Ndjaye, 2007). In the Chinese context, Choi (2010) highlights the commodifying effect of the internationalisation of higher education and the academic capitalism that has ensued. Zajda (2013) similarly links globalization and neoliberalism with the increasing commodification of Australian universities and the 
associated competitiveness at the institutional and individual level, as Shumar (2013) does for the US and Gomes (2010) does for Latin America.

While the majority of critical focus has been on students and the commodification of study, the concomitant commodification of academics has also been explored. Academics, it is argued, have been corporately colonised (Casey, 1995), with neoliberalism getting 'into our minds and our souls' (Ball, 2012). Here, academics become occupied not with the production and transmission of knowledge for social good but with becoming calculable, a commodity that can be measured by research exercise activities and student evaluations of teaching and satisfaction. As a result, we sculpt a public profile not to disseminate knowledge but to boost our personal brand; we publish in journals with high impact factors not for the sake of academic engagement but for career advancement; we network not to develop knowledge in an academic community of practice but as an antidote to precarity.

The commodification of academics has become a truism and few would argue that the nature of academic work and life has been irrevocably changed as a result of neoliberal approaches to higher education that have changed the modes of regulation and governance (Olssen and Peters, 2005). Yet the discourse of the academic as consumed has been under-analysed, the process of how we have become colonised has not been fully theorised and this article therefore attempts that process. Using the conceptual framework of consumerism studies, it argues that, rather than academics being commodified through recent organisational and political impositions, commodification has been achieved through grafting consumerist practices onto the tradition of academic work and university life. Here, the article will consider parallels between the modern academic and her historical predecessor and suggest that the commodification of the self is nothing new within the academy, that it is part of the very DNA of higher education. Secondly, beginning from Bauman's (2007) assertion that individuals in the modern consumer society are both commodity and consumer, the article will move beyond the contemporary academic as passively commodified and explore the process of academic seduction, examining the ways in which academics participate in the practices of consumerism. In this, the article moves from considering the academic solely as consumed to considering the academic as consumer as well.

In this article the term 'academic' is used as a best fit to encompass the wide variety of staff employed within teaching and research in higher education, from established chairs to postdocs employed on temporary contracts. Further, 'higher education' itself is just as diverse, from world-renowned research-intensive institutions to small, community-focused teaching intensives, from those with billions in the bank to those surviving from month to month. However, this article argues that commodification and consumerism are common across the continuum, as much a part of the precariously employed post-doc's working life in Germany as the established chair in the US. What is different is the extent to which the forces of commodification and consumerism influence those working lives. While post-docs are by definition insecure, established academics are increasingly facing their own insecurity if their research outputs and external income are not deemed sufficient. The ancient and modern universities are both measured by the same external accountability processes, however differently they are constructed around the globe. All those who teach are evaluated in some form. All those who research seek to publish where the impact - however that may be defined - will be greatest. All institutions are affected by governmental policy. As such, it would be fruitless to think of the 'academic as consumed' and the 'academic as consumer' as fixed categories or, worse still, a typology. Rather, the intention is to provide two lenses that provide a means to interrogate the interplay between policy, marketisation and academic 
work in all of its heterogeneity. It begins with the established approach to commodification with the academic as consumed.

\section{The academic as consumed}

In discussions of the marketization of education, the overwhelming focus has been on students. With the introduction - and increase - of university fees internationally, students have increasingly been positioned as consumers of higher education (Robertson, 2000; Singleton-Jackson et al, 2010; Woodall et al, 2014), and this trend is intensifying at an ever greater pace. Where once students were described as consumers in cynical accounts of the marketization of HE, in this context the consumerism of students is central to the discourse of university sector internationally and solidifies the transactionalism of contemporary higher education. The result of the consumerist turn has, it is argued, had a profound effect on the nature of academic work and upon academics themselves. Naidoo et al (2011, p1143) suggest that 'public higher-education institutions have traditionally encompassed professional cultures which have been antithetical to market principles and cultures' and these barriers have increasingly been weakened - if not eliminated - by the impact of marketization. The result has left universities the 'unwilling victim' of outside forces (Miller, 2010), laying them bare to the 'forces of commodification' that have developed education into 'a product and process specifically for its 'exchange' rather than for its intrinsic 'use' value' (p1147). The result of this neoliberal incursion has two impacts upon the academic according to Ball (2012, p18). Firstly it introduces the very real business practices of 'financial planning and commercial adventures' into the everyday work of the academic. Secondly, neoliberalism 'gets into our minds and our souls, into the ways in which we think about what we do, and into our social relations with others', irrevocably altering our self-image, remade 'in line with corporate identity' (Harris, 2005) as academic freedom, autonomy and purpose become weakened (Ek et al, 2013). Here, academics become commodified, transmogrified into units of resource, an amalgamation of outputs and practices that can be measured and audited through evaluations of pedagogy and research - in short, the academic becomes consumed.

The contemporary higher education system in the UK provides an ideal example of this perspective on commodification where policy is designed and enacted to position the academic as consumed. There is the Teaching Excellence Framework (TEF) (Office for Students, 2018) that seeks to grade universities in terms of teaching quality that draws on metrics such as graduate outcomes (jobs that are categorised as appropriately 'graduate') and student satisfaction. Currently there is a pilot of the TEF that focuses at a subject level, drawing on metrics on salary after graduation and even, potentially, contact time as proxies for pedagogical quality - both are graded at Gold, Silver and Bronze. There is the Research Excellence Framework (REF), run every six years or so that provides subject panels to peerreview research outputs, impact and research environment; although only in its early planning stages, there is also the Knowledge Excellence Framework (see for example Coiffait, 2018) to assess knowledge exchange. Then there is the National Student Survey, the annual exercise that asks students to rate their courses and institutions and feeds into the league tables and both instances of the TEF. All of these various performative technologies then feed into the plethora of university and subject league tables produced by major newspapers that draw on data such as research quality, entry tariff and spend per student and rank not only UK universities, they then produce meta league tables that rank universities at a global level, sometimes using common metrics (particularly research) and sometimes using reputational surveys completed by academics globally. 
With universities across the globe increasingly driven by metrics, leagues tables and external evaluations of performance, academic work becomes measurable. Taught modules can be considered against a range of key performance indicators (KPIs) (and the very proliferation of the term suggests the adoption of private sector discourses) such as student satisfaction, completion rates and grade outcomes tracked on a five year trend. Research can be considered not only by the number of outputs but by the impact factor of the journal, the altmetrics and cumulatively through an individual academic's h- or i-10 index. Then there is the external funding tally, the number of bids won, especially those with full economic costing. Finally, there is the number of research students attracted by dint of fame and reputation. Thus, each academic can be measured and weighed and, if one were so inclined, attributed a value - a fairly simple valuation could calculate: the income from each individual output submitted to research assessments; the income per full time equivalent students per module taught; the income from each doctoral student attracted; the total external income but especially the full economic costing from each. Salary with 'on-costs' could then be deducted from the final amount rendering a profit or surplus. In this regard, academics can be assigned a 'money equivalence' (Radin, 2001). Here then is the academic as commodity to be consumed within the marketised education system, measured and weighed through the technologies of performativity (Ball, 2003). As a commodity, the academic is compelled to value only that which can be measured leading to a 'deep alienation in the experience of constantly living to perform' and 'feelings of personal inauthenticity and a culture of compliance as externally controlled performance indicators become the constant point of reference' (Lynch, 2005, p 9).

Commodification, then, is a matter of powerlessness, of absorption into a marketised environment where the only option is to submit or exit. Being consumed means becoming inculturated, becoming incorporated within cultures and patterns of work which we may vehemently oppose. Becoming consumed is also a product of necessity. Much attention is paid to the 'precariat', the ever increasing body of staff within universities that are employed on short term, temporary contracts, often with heavy teaching loads that limit research and scholarship. Commodification and consumerism play out within a deeply stratified higher education sector, as deeply stratified as it was at the birth of the university. For those in precarious and insecure work, becoming consumed is not a choice, it has become a necessity, an entry point to fewer and fewer permanent academic posts. The precariat buys-in to inequitable structures of commodification because there is no other choice to gain and retain employment within higher education. However, precariousness in higher education is not always focused on early career academics - within a highly competitive sector, senior academics who are not considered to be contributing to research excellence assessments or student evaluations and satisfaction can similarly find their employment insecure.

The extant literature mostly presents the creation of the commodified academic as a product of neoliberalism, emerging from the post-war period at the earliest. As such, there is a yearning for those pre-neoliberal days when academics could pursue knowledge without the alienating effects of commodification, self-marketing and the perpetual task of maintaining employability. For Sennett, such nostalgia is a product of the new capitalism's emphasis on flexibility, opportunism and illusory choice that fragment contemporary narratives of lives. Underlying this perspective is an ineradicable nostalgia or lamentation: 'consumer culture can never replace the world we have lost, or provide us with selves we can trust, or offer a culture in which we can be truly home' (Sennett, 1998, p99). Also in this discourse is the notion of academic work unsullied by the demands of the market, of industry, of policy drivers - there is a reverentialism of universities as august institutions that should be of a 
higher order of purity. What this view does not account for is the historical perspective that highlights that promoting and marketing the academic self and continually exhibiting employability is at the core of academic work, that universities and academics have always been shaped by the need to attract external recognition and the accompanying rewards and patronage it brings.

\section{The historical context}

There has been little focus on careerism and commodification in the history of the university but it threads through many accounts. In the seminal history of universities in the middle ages, de Ridder-Symoens (2003) identifies a number of forces characterising the professoriate in the middle ages which highlight the impact of external pressures. Among them was increasing government control and increasing corporatism that meant that universities 'lost much of their (medieval) freedom and... no longer had the same wide-ranging freedom to decide [their] own affairs' (p224). As a result, the importance of self-promotion, of launching the signifiers of academic worthiness externally, increased. It found expression in, for example, increasingly elaborate academic dress, the 'outward manifestations of professorial and corporative dignity (ibid, p246) or the self-consciousness of the 'professor's gallery' or the increasing competition with nobility through outward expressions of importance. Elsewhere, in Ferruolo's (1988) work on the Medieval university, the autonomy of the university was 'respected and protected by external authorities as long as the masters were perceived as fulfilling their function of educating men for the needs of society' (p17). The Masters' careerism and ambition meant that this was 'hardly something they had to be coerced into doing', careers after all were shaped by meeting the expectations of those in power, courting patronage through public relations. Grendler (2004), focusing on the universities of the Renaissance and the Reformation, describes how the 'stars' of academia 'spent their time acquiring great reputations in their fields' (p11), organising prominent public disputations to attract attention to himself and his views. Wei (2011) presents a picture of a twelfth century academic world where scholars 'were not valued and did not receive the rewards that they so deserved' ( $\mathrm{p} 46$ ) engendering an environment that was intensely competitive. Here, establishing a reputation as an academic was essential and 'did more than flatter the successful master: it brought him a living' (p50) with wealth and academic fame going hand in hand - 'careers depended on the differences between them and on those differences being widely known' (p56). Baldwin (1995) also discusses the link between an intensely competitive environment and public disputations, this time in seventeenth century France, disputations that cunningly emphasised how essential their patrons were to new discoveries, thereby 'maintaining a clientele' (p408). Gertz (2017) adds a different dimension by detailing how universities in the Middle Ages honed their public image in the fierce competition for the best students, increasingly from international contexts. Weik (2014) argues that the market for academic knowledge emerged in the twelfth century while Scott (2006) highlights the rapid increase of state visitations, interventions and regulation within early modern universities that necessitated academics courting the favour of those in power and shaping academic work to meet their needs.

The history of academia makes clear that there is nothing new about competition in the sector; nor is there anything new about self-promotion; nor even marketing of the self, not ascetically disseminating knowledge, but for reputational and economic gain; nor yet the need to maintain perpetual employability, continually proving one's worth through measurable outcomes. Nor, finally, is there anything new about a yearning for a time of academic purity unsullied by the concerns of the world and the economic and employability imperatives: thirteenth century scholars also 'reminisced about an old order in which they 
imagined a life of greater security and moral certainty' (Wei, 2011, p51). Academia has always maintained a link between economic imperatives, competitiveness and self-promotion yet the majority of the literature presents these as recent phenomena, products of neoliberalism rather than phenomena that are at the very core of academic work and in the very DNA of the university. The history of the university is not exclusively one of pious scholars pursuing knowledge for solely virtuous aims; academic work has never been a pure product unsullied by external concerns. Just as the historical academic arranged public disputations to evidence their intellect and promote their original contributions, so too does the modern academic seek TED Talks and the holy grail of the TV documentary with book tie-in. While our predecessors courted the attention of powerful and wealthy patrons, so do we solicit industry, government and external funders by changing our research to meet their interests. Our academic ancestors were measured by reputation and rank cultivated by external income, publications and attracting students. So too are we. And as academics we bemoan the pressures and influence of the external environment and measurement of our work just as the academic from the past did. Finally, we need to earn a living and finance our personal lives just as our ancestors did. The dissemination of knowledge has always been about self-promotion, marketing and external relations and to minimise this gives academia a reverence that masks the more prosaic - unsavoury to some - realities of academic work.

Yet this is not to suggest that the corporatisation of the historical academic is identical to their contemporary counterpart. Although the history of higher education presents a clear picture of academics engaged in intense competition for personal gain, there is a significant difference in terms of their commodification. This difference is the product of the development of the contemporary consumer society, the 'social arrangement that results from recycling mundane, permanent and so to speak 'regime-neutral' wants, desires and longings into the principle propelling and operating force of society' (Bauman, 2007). Happiness and fulfilment in the consumerist society is not about the gratification of needs - it is about the 'ever rising volume and intensity of desires, which in turn prompt the use and speedy replacement of the objects intended and hoped to gratify them' (ibid, p31). Here is the key difference between the commodification of the academic work of the historical scholar and the work of the modern academic. Commodification and the concomitant marketing of the self in historical terms can be seen as a drive for the gratification of needs, the acquisition of fame and patronage to attract wealth and security, a straight transaction. Such a position sees the reformation of academic work as being solely driven by 'imperatives from the production side' which removes agency from academics, positioning them as 'dupes' within the Frankfurt School tradition (Schor, 2007), powerless against the indomitable process of corporate colonisation. While much of the contemporary literature on the commodification of academic work proceeds from this perspective, that the modern academic is passively commodified by the contemporary university, as Bauman $(2007, \mathrm{p} 12)$ observes, in most accounts of consumerism:

The society of consumers stays neatly divided into things to be chosen and their choosers; commodities and their consumers... in fact, however, the society of consumers is what it is precisely because of being nothing of the sort; what sets it apart from other types of society is exactly the blurring, and ultimately the effacing of the divisions... in the society of consumers no one can become a subject without first turning into a commodity... the most prominent feature of the society of consumers...is the transformation of consumers into commodities. 
As such, when considering the commodification of higher education, what is required is a more nuanced perspective, one that interrogates how corporatization occurs and how academics work within and through the consumerism of the neoliberal university while also accounting for the potential consumerism holds as a means of resistance.

\section{The seduction of academics}

Consumerism is characterised by the association of happiness with desire. In the consumerist workplace, the drive of employees is not solely the gratification of needs in terms of financial reward, it is about inclusion, about entering and remaining within the consumerist economy. It is about increasing one's market value: 'the test they need to pass in order to be admitted to the social prizes they covet demands them to recast themselves as commodities: that is, as products capable of catching the attention and attracting demand and customers' (Bauman, 2007, p 6). Here, the increasing intensity of desires prompts a rapid turnover and replacement of goods - in the broadest sense - to gratify them. In the context of the consumer society, individuals are not forced to become commodified, they are seduced by the promise of gratification from participation within consumerism. However, gratification is stultifying (in a consumerist sense) and to be avoided - 'the promise of satisfaction remains seductive only as long as the desire stays ungratified' (ibid, 46). The DIY job of constant recasting of the commodified self - to remain employable, to achieve recognition, to avoid being invisible must be constantly frustrated to create a perpetual search for fulfilment. This is the seduction of consumerism: creating desires that are then frustrated by the rapid turnover of goods. And if frustrated desire is the driving force or consumerism, the education sector is an ideal exemplar with continual replacement of policies and practices and professional bodies and government agencies and priorities and structures. Here is where policy creates consumerism within higher education. This is where the commodification of academic work is accomplished, not primarily by coercion but by seduction, by nudges, prompts and signposting that seduces the academic and promulgates the continual search for academic employability, of security, of an illusory, ephemeral, academic-whole that exists only in the nostalgic past or the idealised future. To understand the consumption and consumerism of the contemporary academic, to conceptualise how policy seduces, we should consider the 'Diderot Effect' (McCracken, 1990).

Denis Diderot, the eighteenth century editor and author, wrote an essay entitled 'Regrets in Parting with My Old Dressing Gown' (Dioderot, 1769). In the essay, the author gazes around his well-appointed study, elegant and contemporary, a complete transformation from the previous chaotic, dusty and worn room that he occupied before. The room was once simple, threadbare, a wood plank that held up a few books, a few smoky prints without frames, an old rug, and there, in the midst was his old dressing gown, the most 'harmonious indigence'. Despite the dust and the thread-bareness, there was order, there was a consistency derived from that very thread-bareness, and with the harmony of the room came a personal harmony for the author. However, with the introduction of the new dressing gown, an 'imperious scarlet', each of the formerly beloved items looked worn and shabby, suddenly incongruous with the new dressing gown. And so, in an attempt to once more achieve unity within the room, the straw chair was replaced by a leather chair, the rug and the prints removed, the pamphlets and papers once strewn across the old desk were put away in a 'precious bureau'. The removal of the once beloved items left unpleasant voids to be filled with mirrors, a gold and bronze clock and new paintings. So great was the incongruity of the new dressing gown that it destroyed the unity of the room by virtue of being new. The only antidote for Diderot, the only means of regaining that unity - and the contentment he enjoyed as a result of that unity - was to introduce other new things, things that by their very newness would join the 
dressing gown to create a brand new whole. Yet the refurbishment did not bring comfort or completeness for Diderot: gazing at his work he bemoans 'all is now discordant. No more coordination, no more unity, no more beauty'. Instead, he curses the inventor of the dressing gown, the artefact that began the 'ravages of luxury', destroying the unity and comfort of his old, battered room and destroying the unity and comfort of his life within it: 'I was the absolute master of my old robe. I have become the slave of the new one'.

For McCracken, the example of Diderot encapsulates the contemporary consumer society. What we seek as consumers is a Diderot Unity, a 'product constellation' (Flight and Coker, 2016) in marketing terms, 'highly consistent complements of consumer goods' (McCraken, 1990) that match our sense of identity and act as signifiers to others of our status. The 'Diderot Effect' is the result of introducing a new item that disrupts the constellation, rendering every other item unsatisfactory and in need of replacement. Here, then, is the perpetual frustration of desires that propel us to act as consumers. Here is the point of seduction, with consumers locked in a spiral with each new purchase set at a higher level than the last, drawing the complements continually upwards: 'in this pattern each purchase sets a new standard which is repudiated by the purchase to follow, and the consumer is locked into an ever-ascending spiral of consumption' (McCraken, 1990, p127).

If the contemporary academic is commodified then we should adopt the metaphors of marketing and consumerism and imagine our professional selves as Diderot Unities, product constellations consisting of publications, key notes, post-nominals, memberships of associations, doctoral completions. We build our careers and our universities with the aim of achieving a unity, a harmony where the academic may enjoy job security and achieve fulfilment in a knowable, complementary, environment. However, governmental policy shifts promulgate the Diderot Effect, they shift the environment to disrupt the unity of the constellation, they introduce something new that suddenly makes everything else look outdated or irrelevant, stimulating dissatisfaction, seducing the individual academic to once more become engaged in the DIY job of employability. Changes in how research is measured externally prompt shifts in how academics position themselves as 'research-active', where they publish and which funding sources they target. Changes in how student satisfaction is measured lead academics to alter their practice, to provide more individual support or to move from lecture format to small group teaching. Changes in how impact and knowledge exchange is measured lead to changes within external relations and industry collaborations. Each policy shift renders current practice old-hat and in need of replacement, each frustrating the desire of universities, frustrating their goals of league table advancement and a higher external ratings of their teaching and research. And the Diderot effect of policy change on institutions plays out in academic work and academic careers, changing the conception of what it means to be employable. Policy change from this perspective performs a catalytic role in the seduction of academics into consumerist behaviour. The result is a two-fold impact upon academics. Firstly, policy shifts lead to university leaders (who are concerned with their own employability) re-creating their organisations, reframing the structure and reframing the model of 'desirable academic' that will meet the new challenges and attain academic harmony. Secondly, academics read the signs, they horizon-scan and adjust their work to fit the changing landscape, attempting all the time to achieve a consistency, a unity within an ever-shifting environment that will bring them nearer to the illusory academic whole. What is key is that the transformation of academics is not solely a matter of coercion, of senior leaders imposing change; academics themselves become agentive in their own re-creation, they are seduced by the Diderot Effect of policy shifts to continually become born again in the light of new imperatives, new models and new desires. However, as I will discuss in the 
next section, while policy shifts intend to frustrate desires towards a state-mandated academic whole, academic desire can equally be resistant, employing the mechanisms of consumerism to realise a desire to oppose policy, marketisation and the neoliberalist agenda.

\section{The academic as consumer}

Earlier I argued that commodification is a matter of powerlessness, of becoming incorporated within a marketised environment out of necessity, of gaining and retaining precarious employment statuses. But it is not enough for the contemporary academic to merely change their work or to adjust their priorities or to position themselves to adapt to constellationdisrupting policy changes. In a sector where surveillance has become normalised, it is not enough to just be employable; one has to be seen to be employable. Within a marketised higher education sector, universities have 'been reconfigured to produce the highly individualised, responsibilized subjects who have become 'entrepreneurial actors across all dimensions of their lives"' (Davis and Bansel, 2007). Academics are required to create and recreate an academic self that can meet the needs of the corporatized sector, building a portfolio of skills, experiences and badges to mitigate careers that are no longer guaranteed but contingent upon the perpetual policy change-Diderot Effect on academic work, the concept of job security replaced by security in being continually employable (Aldridge, 2003). Here, track record plays second fiddle to the focus on current and future performance as the criteria for reward or sanction: 'what have you done for me lately?' is the guiding principle. CVs are examined for 'velocity' and 'trajectory', external bids won this year, timely doctoral completions, this semester's student evaluations, current citations and altmetrics, in-year publications in journals currently in the top quartile for impact. In Bauman's $(2007, \mathrm{p} 6)$ terms, individuals within the consumerist society are required to become simultaneously the "promoters of commodities and the commodities they promote... the merchandise and the marketing agents'. Furthermore, the 'test they need to pass in order to be admitted to the social prizes they covet demands them to recast themselves as commodities: that is, as products capable of catching the attention and attracting demand and customers' (ibid, p6). This can also be applied to academics who not only become commodities within a consumerist higher education sector but are seduced to become consumers as well, to create a self that is highly visible, a self that communicates the messages of 'employable'.

Here, 'haunted by the spectre of exclusion' (Bauman, 2004), academics must render teaching and research achievements not only visible but strategically visible, easily noticed by the right people at the right time. They are therefore required to engage in 'conspicuous practice', 'the highly public display of practice to convey messages about professional status' (Page, 2017) that differentiate us from our peers. Analogous to Veblen's (1994) notion of conspicuous consumption, conspicuous practice is enacted to create a profile, a personal brand to be cultivated: new publications are embedded within the signature blocks of emails, printed off and left in pigeon-holes; corporate communications teams are engaged to quickly write press releases for personal successes; invitations to keynotes are disseminated far and wide; ResearchGate and Academia.edu profiles are filled with author-accepted versions of publications and academic 'friending' to build followers; Twitter profiles are grown to publicise all aspects of academic life amongst academic networks; LinkedIn profiles, the epitome of the online entrepreneurial self, drawing together suitably polished employment histories with awards, post-nominals, achievements, languages spoken, endorsements from colleagues and students, a collation of numerics for atomised skills such as 'curriculum design' or 'mentoring', a personally tailored ' data double' of pure virtuality' (Haggerty and Ericson, 2000); personal websites are created with studio-quality photos with chin perched on 
hand alternating with action shots of speaking at conferences in front of a suitably packed lecture theatre.

In creating and re-creating the self, the contemporary academic is required to adopt the mantle of the consumer, to consume in order to be consumed and Gabriel and Lang's (2006) work on the 'faces' of consumers provide a useful framework for the application to higher education. Confronted with policy changes that disrupt any semblance of unity, academic consumerism is one of 'identity seeking'. But this is not identity as fixed attributes of self; identity here is a progressive narrative and lies in 'the capacity to keep [that] particular narrative going' (Giddens 1991, p54). For Gabriel and Lang, identity 'can be seen as a story that a person writes and rewrites about him or herself, never reaching the end until they die' (p83). So too do academic careers become narratives in the face of perpetual policy shifts, CVs and LinkedIn profiles constantly updated to present the current and future self, fit, fresh, and continually adapted to the latest policy shift.

But forging an academic identity at the cutting edge of policy and practice requires a different consumerist face, that of the 'consumer as explorer'. In the consumer society, shopping and exploring have become one, with bargain hunting, searching out new products and fashions, new destinations - especially before they become common - all part of the consumer experience. So too is exploration at the heart of the conspicuous practice of academics. However, the narrative of professional self should not be conducted in isolation but in relation to others. There is the exploration of the online profiles of significant academic others, the leading professors in the field, poring over conferences attended and where their research was published and which external partnerships they engaged. Then there are explorers at the same level, those who might also be applying for the same promotion, those who might also be submitting and application to the same external fund, those researching the same phenomena. As Rutherford (1990, p11) argues, 'it's no longer about keeping up with the Joneses, it's about being different from them'. As such, the explorer-consumer academic needs to seek out that which will differentiate him or herself from others, to be the first to find new technology to be integrated into teaching, to identify a significant gap in the literature, to create a new strategy for attracting students, to discover a niche for a new peer reviewed journal. And while exploring, the contemporary academic must also adopt the face of 'consumer as chooser'. Consider the act of research. The academic must search the literature identifying gaps. From the selection, s/he must choose which one best fits the contemporary policy and institutional landscape, the 'hot topic' worthy of promotion or funding. The academic must then choose how to fit the research into his/her daily work, choosing which activities to remove effort and time from (preferably those areas less associated with advancement). Once the research is completed and written up, the academic is then faced with a vast array of journals, exploring departmental priority lists, journal rankings, impact factors, citation indices, reputation among colleagues, the ones preferred and published in by renowned professors and Deans responsible for hiring. Then there is the choice of dissemination vehicle, the optimal means of soliciting citations and boosting altmetrics, carefully selecting the conference that gives the most impact for the money, choosing which delegates to target during the coffee break to recruit to one's network.

The academic consumer as chooser then interacts with the next face, the 'consumer as communicator' - central to consumerism is the 'symbolic function of material goods' (Song, 2003). What we consume tells stories and communicates meaning about who we are, it communicates social categories and hierarchies and, in this context, how valued we can be and how well we respond to continually changing policy emphases. In this, what is important 
is not what individual goods communicate - the message transmitted by a single journal article in the top quartile of the Thomson Reuters ranking by itself is limited. What is of prime concern is how each individual item links to the other elements of the employability constellation, the message that the 'chain of signifiers' (Baudrillard, 1998) in its entirety communicates. To return to Diderot, the message of the new dressing gown is beside the point; what is important is the message of the entirely new room that the dressing gown prompted.

To some, the idea that academic work is analogous to consumerist behaviour will be heretical, a cheapening of the pure search for knowledge and pedagogy enshrined within the university mission. But this is from the perspective that reverentialises universities, that puts academic work - and academics - on a pedestal far removed from the prosaic behaviours of consumerism. As we have seen above, such activities are part of the very DNA of higher education, a consistent feature since the birth of the university. Not only consistent but essential - few would argue that universities should pursue knowledge separate from society and regardless of how it is measured, few would argue against impact, a social good arising from our research. We may prefer the term 'dissemination' but it is marketing by another name. We may prefer 'public engagement' over 'public relations' but, in the end, they look the same. We may bemoan the over-production in retail consumerism but we fail to equate it to the fact that up to $77 \%$ of peer reviewed articles are never cited five years after publication (Baker, 2018) and include references to scholarly work that has not even been read (Bauman, 2007). We fail to see the correlation between rapidly multiplying goods in vast retail outlets and the ever-multiplying panoply of peer reviewed journals. We write eviscerating articles about the marketing of degrees like new cars yet become incandescent when our web-profile misses out a doctoral completion. For Gabriel and Lang (2006, p93), 'the consumers' freedom to choose from 200 different beers, 600 different motor cars or 160 different magazines is no less meaningful than the intellectuals' freedom to read or write what they please'. In this, there is a hierarchy of legitimacy (Bourdieu, 1984) that separates the supposed purity of academic work from prosaic techniques for promoting the knowledge produced, attracting funding and building a professional profile. It is this hierarchy that allows us as academics to criticise the excess of 200 different beers in a supermarket without the same criticism of 200 different journals on the same subject in our libraries.

\section{Consumerism as resistance}

However, although the Diderot effect of policy changes can be seductive, the academic as consumer does not automatically equate to becoming subservient or colonised in the way described earlier for the academic as consumed. Consumerism is not that straightforward and consumerist resistance is not only possible, it is inevitable and, potentially, fruitful. Yet this is not the paradigm of overt and coordinated resistance; this is everyday resistance (Scott, 1985), routine resistance (Prasad and Prasad, 1998) that operates within existing structures and cultures. The consumer as resister (Gabriel and Lang, 2006) does not always resist by rejecting consumerism (which is virtually impossible given our need to consume). Instead, resistance here is about the 'discovery of uses for objects distinctly different from those assigned to them by manufacturers and merchandisers' (ibid, 138). As such, it is a rejection of the 'authority of the producer' (Abercrombie, 1994, p51), a grafting of alternative meanings from the authority of the consumer instead. Consider the 1980s trend for ripped and frayed jeans: consumers bought pristine jeans then deliberately ripped them, rejecting the intentions and authority of the producer. Then there was the craze (inspired by the 1980s pop group Bros) for wearing beer bottle tops on shoes - this time, the functional meaning was subverted to become a grassroots fashion trend. Consumerist resistance here was not in overt 
means like a boycott, it was 'ambiguous accommodation' to use Prasad and Prasad's (1998) terms, working within established patterns, practices and products to gain or retain subjectivity.

In higher education we find similar patterns of consumerist action: consider those researchers who work in the fields of race or feminism for example, both fields that are highly critical of the structures and power practices within universities that remain inequitable in terms of the representation of academics of colour and women, especially at senior levels. These fields produce internationally recognised research published in journals with high impact factors, those same journals that a marketised university covets. These fields hold international conferences highly esteemed by universities yet they often provide a forum for critical analysis of the university. Research funding is allocated to these same fields that, in turn, increases the profile of both the individual academic and the university within which they work. Yet, despite using the mechanisms of commodification such as established journals, university conference and funding councils, the meanings ascribed are far from neoliberal, far from incorporation and far from subservience. Away from research, consider the academic teaching a prescribed departmental curriculum that may retain traditional patterns of patriarchy or white privilege, in the reading list for example. Here, the academic may add new suggested readings, or new interpretations of texts that provide an alternative to prescription. They may hold individual meetings with students where they interrogate the assumptions within the curriculum that energise students and create highly scoring module evaluations, evaluations that boost departmental and university achievement in league tables. Consider also the female academic of colour who fashions a sophisticated external profile consisting of Twitter, Researchgate, LinkedIn and even her own website, all reproducing herself as commodity but for the purpose of resisting traditional hierarchical measures of esteem that seek to block women of colour from advancement. In these cases, academics still act within the consumerist paradigm, they are still engaged in conspicuous practice. The difference is the locus of meaning, the exploitation of existing frameworks and practices for their own means - they are operating under la perruque, 'the wig' in de Certeau's (1984) terms where 'the worker's own work [is] disguised as work for his employer' (p24).

Conspicuous practice from this perspective is resistant, a means of achieving alterative aims within existing commodities that universities covet. Meaning within academic consumerism is therefore reappropriated from the neoliberalism agenda, alterative aims are achieved, commodification is simultaneously resisted and achieved with new, resistant meanings. In this, Bauman's notion of frustrated desire propulsion to consumerim holds trues - the difference is that the frustrated desire is not necessarily attached to self-promotion for the purposes of aggrandisement or employability or becoming successful within a marketised university sector. It is instead attached to a frustrated desire to oppose: to oppose discrimination, to oppose inequitable structures, to oppose the forces of neoliberalism. Finally, potentially to oppose consumerism itself, all the while using the products and mechanisms of consumerism itself.

\section{Conclusion}

If Twitchell (1999) is right that humans are consumers by nature then it may be argued that so too are academics. And if he is also right that consumers, rather than being dupes, are rational and self-aware of their consumerist behaviours then so too are academics, whether we label it as such or not. But more than this, there is a pleasure in academic consumerism. For Bauman (2007), pleasure has been co-opted into the capitalist project and it is pleasure that allows individuals to endure the 'rigours of life under the capitalist reality principle, that is, alienating work, the threat of unemployment or worse' (Gabriel and Lang, 2006). For 
Twitchell (1999, p27), consumers have 'created a surfeit of things because we enjoy the process of getting and spending' and so it is in academia. There is a pleasure in the exploration of academic work and finding a niche, in choosing just the right journal, in communicating our original contribution to our peers and the public. There is a pleasure in attracting external funds and achieving academic fame. Whether we - or more importantly, the public - need another journal further atomising a cognate area is besides the point; whether we produce one of the $77 \%$ of articles that are never cited after five years is not the issue. The pleasure of academic work, however consumerist it might be, however far removed from the pure ideal of the university, ensures a steady supply of new recruits to a sector that offers ever fewer opportunities for a permanent academic career. The neoliberal incursion into the academy has been grafted onto the historical practices of the academic, where self-promotion and dissemination can be indistinguishable, where careers have always been built on gaining a reputation from being seen by the right people at the right time. But while academic work may always have been commodified, the real impact of neoliberalism may be the perfection of this process while simultaneously seducing academics into becoming consumers. However, desire and pleasure in academic work cannot always be prescribed. The intentions of policy do not necessarily create academics that become willingly consumed and consumerist. Academic desire can equally be resistant, it can exploit the mechanisms and mediums of consumerism to attack the commodification of academic work, to provide critiques of policies that seek to colonise. Frustrated academic desire can lead not only to the creation of consumable identities, it can lead to the creation of oppositional identities that subvert the intended meanings of policy and the authority of policy-makers. And in this academics may find a pleasure within alterative subjectivities greater than any pleasure that could be prescribed.

\section{References}

Abercrombie, N. 1994. "Authority and conumser society”. In Keat, R., Whiteley, N. and Abercrombie, N. eds., The authority of the consumer. London: Taylor \& Francis.

Aldridge, A. 2003. Consumption. Cambridge: Polity Press

Baker, S. 2018. How much research goes completely uncited?

Baldwin, M., 1995. "The snakestone experiments: An early modern medical debate". Isis 86 (3): $394-418$

Ball, S. 2003. "The teacher's soul and the terrors of performativity". Journal of Education Policy 18 (2): 215-228

Ball, S. 2012. "Performativity, Commodification and Commitment: An I-Spy Guide to the Neoliberal University". British Journal of Educational Studies 60 (1): 17-28

Baudrillard, J. 1998. The consumer society: myths and structures. London: Sage

Bauman, Z. 2004. Europe. Cambridge: Polity Press

Bauman, Z. 2007. Consuming life. Cambridge: Polity Press

Bourdieu, P. 1984. Distinction: A social critique of the judgement of taste. London: Routledge

Boyd, C. 2018. "A beginner's guide to the office for Students". WonkHE. http://wonkhe.com/blogs/a-beginners-guide-to-the-office-for-students/

Casey, C. 1995. Work, self and society: After industrialism. London: Sage.

Choi, P.K., 2010. 'Weep for Chinese university': A case study of English hegemony and academic capitalism in higher education in Hong Kong. Journal of Education Policy, 25(2), pp.233-252.

Coiffait, L. 2018. "What's the latest with the knowledge exchange framework (KEF)?" 
https://wonkhe.com/blogs/whats-the-latest-with-the-knowledge-exchange-frameworkkef/

Davies, B. and Bansel, P. 2007. "Neoliberalism and education". International Journal of Qualitative Studies in Education 20 (3): 247-259

de Ridder-Symoens, H., 2003. A history of the university in Europe: Volume 1, Universities in the Middle Ages (Vol. 1). Cambridge: Cambridge University Press.

Department for Education (2016) "Research Excellence Framework (REF) review: Building on success and learning from experience" https://www.gov.uk/government/publications/research-excellence-framework-review

Diderot, D. (1769) "Regrets for my Old Dressing Gown". https://www.marxists.org/reference/archive/diderot/1769/regrets.htm

Ek, A.C., Ideland, M., Jönsson, S. and Malmberg, C., 2013. The tension between marketisation and academisation in higher education. Studies in Higher Education 38 (9): 1305-1318

Erkkilä, T., 2014. Global university rankings, transnational policy discourse and higher education in Europe. European Journal of Education, 49(1), pp.91-101.

Ferruolo, S.C., 1988. “'Quid dant artes nisi luctum?': Learning, Ambition, and Careers in the Medieval University". History of Education Quarterly 28(1): 1-22

Flight, R.L. and Coker, K.K. 2016. "Brand constellations: reflections of the emotional self". Journal of Product \& Brand Management 25 (2): 134-147

Fumasoli, T., Goastellec, G. and Kehm, B.M., 2015. Academic careers and work in Europe: Trends, challenges, perspectives. In Academic Work and Careers in Europe: Trends, Challenges, Perspectives (pp. 201-214). Springer, Cham.

Gabriel, Y. and Lang, T. 2006. The unmanageable consumer. London: Sage

Gertz, S.K., 2017. "Universities and the humanities, then and now". Journal of Further and Higher Education 41(6): 844-856

Giddens, A., 1991. Modernity and self-identity: Self and society in the late modern age. Cambridge: Polity Press.

Gomes, A.M., Robertson, S.L. and Dale, R., 2012. The social condition of higher education: globalisation and (beyond) regionalisation in Latin America. Globalisation, Societies and Education, 10(2), pp.221-245.

Gov.UK 2018. "Graduate outcomes (LEO): 2015 to 2016”. UK Government https://www.gov.uk/government/statistics/graduate-outcomes-2015-to-2016

Grendler, P. F. 2004. "The universities of the Renaissance and Reformation". Renaissance Quarterly 57 (1): 1-42

Gyimah, S. 2018. Twitter, $27^{\text {th }}$ June. https://twitter.com/SamGyimah/status/1011530092965715968

Haggerty, K and Ericson, R. 2000. "The surveillant assemblage". British Journal of Sociology 51(4): 605-622

Harris, S. 2005. "Rethinking academic identities in neo-liberal times". Teaching in Higher Education 10 (4): 421-433

Hood, C. 1991. "A public management for all seasons?" Public Administration 69 (1): 3-19

Kwiek, M. and Antonowicz, D., 2015. The changing paths in academic careers in European universities: Minor steps and major milestones. In Academic work and careers in Europe: Trends, challenges, perspectives (pp. 41-68). Springer, Cham

Lynch, K. 2005. "Neo-liberalism and Marketisation: The Implications for Higher Education". Keynote Paper presented to the European Educational Research Conference (ECER) UCD Dublin, September 5-9th 2005

McCracken, G.D. 1990. Culture and consumption: New approaches to the symbolic character of consumer goods and activities. Bloomington: Indiana University Press 
Miller, B. 2010. "Skills for sale: what is being commodified in higher education?" Journal of further and Higher Education 34 (2): 199-206

Naidoo, 2003. Repositioning Higher Education as a Global Commodity: Opportunities and challenges for future sociology of education work, British Journal of Sociology of Education, 24:2, 249-259

Naidoo, R., Shankar, A. and Veer, E., 2011. "The consumerist turn in higher education: Policy aspirations and outcomes". Journal of Marketing Management 27(11-12): 1142-1162

Office for Students (2018) "What is the TEF?" https://www.officeforstudents.org.uk/adviceand-guidance/teaching/what-is-the-tef/

Olssen, M. and Peters, M.A., 2005. "Neoliberalism, higher education and the knowledge economy: From the free market to knowledge capitalism". Journal of education policy 20 (3): 313-345

Page, D. 2017. "Conspicuous practice: self-surveillance and commodification in English education". International Studies in Sociology of Education. Online First. DOI: 10.1080/09620214.2017.1351309

Prasad A. and Prasad, P. 1998. "Everyday struggles at the workplace: the nature and implications of routine resistance in contemporary organizations". Research in the Sociology of Organizations, 15: 225-257

Radin, M. 2001. Contested Commodities: the Trouble with Trade in Sex, Children, Body Parts, and Other Things. Cambridge, MA: Harvard University Press

Robertson, D., 2000. "Students as consumers". In Scott, P. (Ed) Higher Education Reformed, 77-92. London: Falmer Press

Rutherford, J. 1990. "A place called home: Identity and the cultural politics of difference". In J. Rutherford (ed.) Identity: community, culture, difference. London: Lawrence and Wishart, p1-20

Sall, H.N. and Ndjaye, B.D., 2007. Higher education in Africa: between perspectives opened by the Bologna Process and the commodification of education. European Education, 39(4), pp.43-57

Schor, J.B. 2007. "In defense of consumer critique: Revisiting the consumption debates of the twentieth century". The Annals of the American Academy of Political and Social Science 611 (1): 16-30

Scott, J. 1985. Weapons of the Weak: Everyday forms of Peasant Resistanc. Yale University Press, New Haven, USA

Scott, J. C. 2006. "The mission of the university: Medieval to Postmodern transformations". Journal of Higher Education 77 (1): 10-13

Sennett, R., 1999. The corrosion of character: The personal consequences of work in the new capitalism. New York: Norton

Shumar, W., 2013. College for sale: A critique of the commodification of higher education. London: Routledge

Singleton-Jackson, J.A., Jackson, D.L. and Reinhardt, J., 2010. "Students as consumers of knowledge: Are they buying what we're selling?" Innovative Higher Education 35 (5): 343-358.

Song, E., 2003. "Commodification and consumer society: A bibliographic review". The Hedgehog Review 5 (2): 109-122

Twitchell, J.B., 1999. Lead us into temptation: The triumph of American materialism. New York: Columbia University Press

Veblen, T. 1994. The Theory of the Leisure Class. New York: Dover

Wei, I.P. 2011. "From twelfth-century schools to thirteenth-century universities: the 
disappearance of biographical and autobiographical representations of scholars". Speculum, 86 (1): 42-78

Weik, E. 2014. "The Market for Academic Knowledge: Its Historical Emergence and Inherent Tensions". British Journal of Educational Studies 62 (4): 431-447

Woodall, T., Hiller, A. and Resnick, S. 2014. Making sense of higher education: Students as consumers and the value of the university experience. Studies in Higher Education 39 (1): 48-67

Zajda, A.J., 2013. Globalization and neo-liberalism as educational policy in Australia. In Neo-liberal Educational Reforms (pp. 182-201). Routledge. 